\title{
Exploring environmental constraints that hinder the physical activity of middle school girls in daily life: Photo-Voice
}

\author{
Lee, GyuIl* \\ Kyungpook National University
}

\begin{abstract}
[Purpose] The purpose of this study was to explore environmental constraints that hindered the physical activity of female students in daily life, and then to provide alternatives to improve the problems based on the social ecological model. [Methods] Research participants were twelve female students to be selected in two schools(Norang, Parang middle school), the process of data collection(orientation, photovoice implementation, focus group interview) and analysis(choosing a photo, contextualizing, subjecting) were conducted according to the Photo-voice. [Results] The constraints of physical activity in daily life were categorized on 'playground as like a desert'(leisure domain), 'space of recess and in-active play'(family domain), 'transportation replaced by mom and dad car'(transportation domain), 'space of the only exercise as well as reproduction of gender discrimination'(school domain). [Conclusions] The environmental constraints were analyzed as academic, physical, daily living, socio-cultural environment. Lastly, alternatives for promoting physical activity of female student were proposed in the level of organization, community, public policy based on the social ecological model.
\end{abstract}

Key words: female student, physical activity in daily life, environmental constraints, social ecological model, photo-voice

\section{서 론}

신체활동만큼 건강에 효과적이고 경제적인 활동은 없 다. 달릴 수 있는 의지와 체력만 있다면 누구나 신체활동 의 효과를 누릴 수 있다. 그러나 신체활동 딜레마로 알려 진 "신체활동의 효과에 대해 아는 사람은 많아도, 일부의 사람만이 참여한다."(Berger, 1996, p. 330)는 문구처 럼, 신체활동의 효과를 충분히 누리는 사람은 일부에 지 나지 않는다. 성인기 신체활동의 감소 현상이 지속되고

논문 투고일 : 2020. 04. 14 .

논문 수정일 : 2020. 05. 18.

게재 확정일 : 2020. 06. 09.

* 교신저자 : 이규일 (mauri94@knu.ac.kr).

* 이 논문은 2019년 대한민국 교육부와 한국연구재단의 인문사 회분야 중견연구자지원사업의 지원을 받아 수행된 연구임 (NRF-2019S1A5A2A01042454).
있으며, 아동과 청소년 역시 뚜렷한 감소세를 보이고 있 다(Slater \& Tiggemann, 2010). 특히, 젠더에 의한 신 체활동 차이(남>여)는 다른 요인들(예, 인종, 사회경제적 위치, 민족, 비만이나 체중, 민족 등)에 비해 가장 보편적 인 현상으로, 같은 연령대의 여성의 신체활동 수준은 남 성에 비해 현저히 낮다(CPPSE, 2013). 특히 우리나라 10 대 여학생의 신체활동은 국외 동일 연령대의 여학생들 에 비해 저조하고, 남녀 학생 간 차이 역시 심한 편이다 (Kang \& Lee, 2015). 이러한 측면에서, 여학생 신체활 동 문제에 관심을 기울일 필요가 있다.

중학교 학령기는 여학생 신체활동의 중요한 변화가 일 어나는 시기이다. 구체적으로, 여학생의 신체활동 감소세 는 9 14세 연령 범위에서 나타나고(Barnett et al., 2002), 감소의 폭 역시 뚜렷하게 나타나는 시점은 12 세이 다(Telama \& Yang, 2000). 우리나라 여학생의 신체활동 
추이를 학교급별로 분석한 Kang \& Lee(2015) 역시 중학 교 시기부터 신체활동의 감소가 뚜렷이 나타난다고 강조한 다. 실제로 중학교 학령기 좌식행동 비중은 평균 10 20분 이상 증가하고(Pearson et al., 2017), 우리나라의 경우, 여가시간 신체활동에 전혀 참여하지 않는 10 대 여자 청소 년의 비율은 $47.6 \%$ 에 이른다(MCST, 2018). 결과적으 로, 중학교 여학생은 젠더와 시기(연령) 문제가 결합된 신 체활동 문제를 경험한다. 이렇게 볼 때, 중학교 여학생의 신체활동 문제는 다른 학교급보다 시급한 과제이다.

그동안 청소년 신체활동 문제는 학교 체육활동을 중심 으로 처방되어 왔다. 첫째, 체육수업의 신체활동량을 높 이기 위한 연구가 제기되어 왔다. 대표적으로 미국의 체 육교육당국(National Association for Sport and Physical Education, NASPE)은 좋은 체육수업의 양적 기준을 수업시간 대비 중-고강도 신체활동 (Moderate to Vigorous Physical Activity, 이하 MVPA) 비율 50\% 이 상으로 삼고(NASPE, 2005), 체육수업용 신체활동 증진 프로그램(SPARK, CATCH-PE, LEAP-PE, SHL, SPEM 등)을 개발 및 적용해 왔다(Lee \& Hong, 2017). 국내에서는 이러한 국외의 프로그램을 체육수업에 적용 해 그 성과를 분석해 국내 체육수업에의 도입을 모색하거 나, 국내 학교 현장에 적합한 신체활동 증진 프로그램을 개발해 체육수업 신체활동을 개선해 왔다(Lee, 2019). 둘째, 체육수업 외에 학교 일과를 중심으로 오전(before school), 점심 시간과 쉬는 시간(during school), 방과 후(after school) 등의 시간을 활용한 틈새체육활동 프로 그램을 통해 학생들의 신체활동을 증진시키고자 노력해 왔다(Sarkin et al., 1997; Song et al., 2010). 셋째, 비 만 학생들이나 저체력 학생들과 같은 신체활동이 부족한 학생들을 대상으로 한 체력운동교실 등의 추가적인 프로 그램을 운영해 왔다.

이러한 학교 체육 중심의 신체활동 정책은 학교 내에 서의 신체활동을 증진시켰다는 의의가 있지만, 기대만큼 의 전이 효과가 나타나지 않음에 따라, 청소년 신체활동 증진에 한계가 있다는 비판을 받고 있다(CPPSE, 2013). 생활영역별(학교, 가정, 여가, 교통) 신체활동 수 준을 분석한 국내 연구들은 국외에 비해 신체활동 수준은 낮으나 학교영역에서의 의존도는 상대적으로 높다고 밝 히고 있다(Kang \& Lee, 2015; Lee \& Kang, 2015). 신
체활동 전문가들은 학교체육의 중요성을 강조하면서도, 청소년에게 충분한 신체활동을 제공하기 위해서는 신체 활동 정책이 일상생활에 초점을 두어야 한다고 강조한다 (Castelli et al., 2014). 국외의 활발한 논의에 비해, 국 내에서는 여전히 학교 체육활동을 중심으로 신체활동 증 진 방안을 모색하고 있다(Lee, 2014). 이러한 측면에서, 여학생 신체활동 문제를 일상생활로 확대하기 위한 논의 가 필요하다.

여학생 신체활동 연구들은 크게 상관요인과 제약요인 분석으로 구분된다. 전자의 연구들이 주로 양적연구방법 을 활용해 신체활동의 $(+)$ 요인을 밝히는 데 주력한다면, 후자의 연구들은 질적연구방법을 활용해 여학생의 신체 활동 (-)요인에 집중한다(Sallis et al., 2000). 여학생의 일상생활 신체활동 문제에 관한 국내 연구가 미비한 상황 에서 두 접근의 연구가 모두 요청되지만, 증진 $(+)$ 요인 의 경우 국내·외 차이가 크지 않은 반면, 문화적 특수성과 실제의 삶의 영역을 관장하는 제약요인은 국외의 분석을 그대로 국내 상황이나 대상에 적용하기 어렵다. 또한, 제 약요인 연구는 신체활동 상황에서 야기되는 소외 대상의 문제들을 해결하기 위한 정책(보호 관점의 정책)을 수립 하는데 기여한다. 신체활동 정책은 보호 관점에서 점진적 으로 증진 관점으로 이동하는 경향을 보여 왔다(CPPSE, 2013). 즉 우선 보호하고 난 후 증진하는 것이 정책의 기 본 원칙이라는 것이다. 이런 측면에서, 여학생의 일상생 활 신체활동 제약요인을 살펴보는 한편, 이를 해결하기 위한 대안을 모색하기 위한 연구가 우선될 필요가 있다.

여학생 일상생활 신체활동 문제를 분석한 연구들을 살 펴보면, 첫째, 개인이 직면하고 있는 개별 요인들을 병렬 적으로 제시한 연구들이 있다(Lee, 2014; Mikaelsson et al., 2019). 대표적으로, Lee(2014)는 여고생이 직면 하는 문제를 ' 가 없기 때문'(시간, 힘, 의지, 공간, 꺼리 와 사람)과 ' 때문'(스마트폰, 자동차, 시선, 규칙)으로 밝히고 있다. 둘째, 젠더 관점에서 여학생 신체활동 문제 를 분석한 연구들(Slater \& Tiggemann, 2010; 2011) 로써, Slater \& Tiggemann(2010)은 남학생과 대비되 는 여학생의 신체활동 제약문제를 젠더 이데올로기, 학교 과제, 신체활동 참가 옵션의 제약 등으로 밝히고 있다. 셋 째, Thompson et al. (2005)은 학교급별 여학생 집단 (여초생, 여중생, 여고생)의 문제를 분석하며 각 학교급 
별 여학생들의 신체활동 제약 특성을 밝히고 있다. 이상 의 선행연구들은 신체활동 문제를 인구통계학적 요인, 심 리적 요인, 행동적 요인, 사회적 요인 측면에서 폭넓게 이 해할 수 있는 자료를 제공하지만, 환경적 맥락에서 신체 활동 문제를 해석하는 데 한계를 안고 있다(Biddle et al., 2011; Nahas et al., 2003).

환경적 접근은 인간 행동이 환경적 자극에 의해서도 추동된다고 가정한다(Morton et al., 2016). 즉, 환경적 자극에 의해 특정 행동이 유발되거나 제약될 수 있다는 것이다 (Green et al., 1996). 환경적 접근은 기본적으로 생태학적 접근을 취하며, 이때 가장 활발하게 적용되는 이론이 사회생태학 모형 (social ecological model)이다. 이 모형에 따르면, 인간 행동은 개인과 환경의 상호작용 결과로 나타나며, 행동을 다음의 다섯 가지 수준으로 설 명한다(Sallis et al., 1999; 2008). 개인 내적 (intra-personal) 수준은 개인의 지식이나 신념, 기능, 체력 등과 같이 개인이 내적인 요인을 말한다. 개인 간 (inter-personal) 수준은 신체활동에 영향을 미치는 소 규모 사회적 관계로서 가족이나 친구들 간의 관계가 대표 적이다. 조직 (organizational)과 공동체 (community) 수준은 각각 개인이 속해 있는 기관이나 지역의 신체활동 시설, 문화, 분위기 등과 관련된 요인들이다. 공공 정책 (public policy) 수준은 국가나 지자체의 신체활동 관련 정책에 의해 영향을 받는 요인들이다(Kim \& Lee, 2013a). 결국, 인간 행동은 각 수준의 단독 요인에 의해 서뿐만 아니라, 각 수준들 간의 다양한 결합과 상호작용 을 통해 일어난다는 것이다. 이러한 측면에서, 신체활동 맥락을 이해하기 위해서는 개인을 둘러싸고 있는 환경적 요인들에 대한 이해가 요청된다.

따라서, 본 연구에서는 첫째, 중학교 여학생이 경험하 는 일상생활 신체활동의 제약요인을 살펴보고자 한다. 둘 째, 사회생태학 모델에 근거해 제약문제를 해결하기 위한 방안을 제안하고자 한다.

\section{연구방법}

포토보이스는 경험과 인식에 관한 사진 자료를 통해 텍스트가 가지고 있는 재현의 한계를 극복하고자 하는 질
적연구 기법으로(Wang, 2006), 소외나 불평등 등과 같 이 특정 문제에 직면하고 있는 사람들을 이해하는데 적합 한 연구기법으로 평가받고 있다(Kim \& Lee, 2013a). 이에, 본 연구에서는 포토보이스 기법을 활용해 여학생이 직면하고 있는 일상생활 신체활동의 문제를 파악하고자 한다.

\section{연구참여자}

본 연구에서는 다음 두 가지 기준을 중심으로 연구참여 자를 선정하였다. 첫 번째 기준은 우리나라의 일반적인 여 중생의 삶을 크게 벗어나지 않는 학생을 선정한다는 것이 고, 두 번째 기준은 일상생활 전반의 신체활동이 저조한 학 생을 선정한다는 것이다. 이 기준들에 따라, $\mathrm{A}$ 시와 $\mathrm{B}$ 시의 도시 지역 학교 중, 학업을 지나치게 강조하거나 간과하지 않는 중간 정도 학군의 학교 각 한 곳을 연구 학교(파랑중, 노랑중)로 선정하였다. 연구학교의 각 학년 학급수는 6 개 반 이었으며, 해당 학교 선생님들에 따르면, 학생들 대부분 은 학업을 위해 주 3회 정도 학원에 다니고 있었다. 연구참 여자 선정을 위해 연구 학교 2학년 학생들을 대상으로 지난 7일간의 신체활동량을 평정할 수 있는 '국제 신체활동 설문 지'(International Physical Activity Questionnaire, IPAQ)를 활용해 일상생활 신체활동 수준을 측정하였다. 학생 개인의 신체활동 점수를 등급에 따라 구분하고 낮은 등급1)에 해당하는 여학생을 선정하였다. 선정된 명단을 체육교사에게 제공해 연구문제에 대해 유의미한 이야기 를 제공해 줄 수 있는 여학생을 추천받았고, 학생과 학부 모 모두 연구 참여에 동의한 12 명의 여학생을 연구참여 자로 선정하였다. 선정 과정에서 연구의 의의와 절차에 대해 충분히 설명하였으며, 연구참여자의 특성은 〈Table 1)과 같다.

신체활동이 저조한 여학생의 특성은 무엇인가? 연구 진은 신체활동 참여 의지가 없는 학생으로 규정하며 연구 를 시작하였다. 연구 학교 체육교사들 역시 연구진과 비 슷하게 생각하였다.

1) IPAQ 공식 홈페이지 자료에 따르면, 낮은 등급은 3 일 이상 최소 하루 20 분 이상의 고강도 활동이나 5 일 이상 최소 하루 30 분 이상 중강도 활동 또는 주당 최소 $600 \mathrm{MET}$ 미만의 신 체활동 점수대를 의미한다(Patterson, 2010). 
Table 1. Characteristics of research participants

\begin{tabular}{|c|c|c|}
\hline School & Name & Characteristics and Features \\
\hline \multirow{6}{*}{ Parng } & Ilwol & Ilwol played Taekwondo, when she was young, but now she is not active in physical activities. \\
\hline & Ewol & Ewol is rather shy and introverted. And she is not active in PE class, but participates diligently in a given task. \\
\hline & Samwol & $\begin{array}{l}\text { Samwol is really an bright and funny girl, but her physical ability is very low, so she is an evasive student in PE } \\
\text { class. }\end{array}$ \\
\hline & Sawol & Sawol doesn't like physical activity and is a passive student in the PE class. \\
\hline & Owol & Owol is narrow-minded in relationship and introverted, and is passive in athletic activities. \\
\hline & Yuwol & $\begin{array}{l}\text { Yuwol has lots of complaints, and doesn't like physical activities, but tends to work hard on given tasks in PE } \\
\text { class. }\end{array}$ \\
\hline \multirow{6}{*}{ Norang } & Chiwol & $\begin{array}{l}\text { Chiwol is a student with a wide and active social relationship, but in PE class, she seems to be attracted to friends } \\
\text { rather than voluntary. }\end{array}$ \\
\hline & Palwol & $\begin{array}{l}\text { Palwol participates in task activities in PE class, but tends to aim for external rewards, such as praise, rather than } \\
\text { fun or pleasure of physical activity. }\end{array}$ \\
\hline & Guwol & Guwol is a sincere student in the PE class, but is passive in other physical activities out of PE class. \\
\hline & Siwol & Siwol participates in PE class faithfully and has good friendship, but is passive in physical activity itself. \\
\hline & Sib-ilwol & Sib-ilwol is a student who has low physical abilities but tries hard. \\
\hline & Sib-ewol & Sib-ewol is a student who works hard in the PE class, but has no interest in physical activities out of PE class. \\
\hline
\end{tabular}

그럼, 잘 안 움직이고 할 의지가 없는 애를 추천드리면 되나요? -노랑중 체육교사-

그러나, 자료의 분석과정에서 신체활동이 저조한 여학 생에 대한 새로운 개념을 발견할 수 있었다. 이러한 발견 은 연구의 결과이기도 하지만, 연구참여자의 특성과 관련 된 사항이기 때문에, 연구참여자 특성과 관련한 정보로 제시하고자 한다.

십일월 학생은 일상생활 신체활동을 제약하는 요인으로 자기 자신을 상징하는 사진을 찍어 왔다(Figure 1 참조).



Fig. 1. my name written on the notebook

이 사진은 역사 공책에 적혀 있는 제 이름을 찍어 온 거에 요. 그냥 제 의지가 없어서 운동을 하지 않는 것 같아서요. 거의 마지막에 찍은 사진인데 거의 다 찍고 나니까 제가 안 하는 거더라고요. 그래서 찍어 왔어요. -Sib-ilwol((십일월)-
포커스 그룹 면담(Focused Group Interview, FGI) 에서 이 사진은 많은 학생들의 동의를 얻었으며, 연구참 여학생들로부터 다양한 일상생활 신체활동의 제약요인 을 일으키는 가장 근본적인 문제가 자기 자신의 '의지 부 족'에 있음을 인정하게 하였다. 이런 점에서, 연구참여자 들의 첫 번째 특성은 신체활동에 대한 의지가 부족한 여 학생이다.



Fig. 2. a snack

간식을 찍어 온 것은 이걸 먹으면 배가 부르잖아요. 그러 면 운동하기 싫어지기 때문이에요. - IIwol(일월)-

두 번째 특성은 먹을거리 사진에서 찾을 수 있다. 연구 참여자들이 찍어 온 사진들을 분류했을 때 가장 많은 분 류명에 들어간 사진이 바로 먹을거리 사진이었다. 총 
224장의 사진 중 21장이 먹을거리(예, 과자, 주스, 초콜 릿, 피자, 떡볶이, 아이스크림 등)와 관련된 사진이었을 정도였다. 대표적인 사진으로〈Figure 2〉를 들 수 있으 며, 이 사진을 중심으로 진행된 대화 내용을 통해 간식(혹 은 먹을거리)의 의미를 파악할 수 있다.

연구자: 다른 학생들도 이런 먹는 것들(피자, 음료수, 과자, 편의점, 치킨 등) 정말 많이 찍어 왔는데 일월 학생의 생각에 동의해요?

Samwol(삼월): 네. 완전 동의해요. 배가 부르면 그냥 운동 하는 것을 포기하게 되요. 운동하는 이유가 다이어트 때문인데 먹었으니까 운동할 필요가 없는 거잖아요. 배 가 부르면 그냥 다이어트 포기하는 거가 되는 거예요.

Ewol(이월): 이런 거 먹으면 어차피 해도 안 된다는 생각이 들고 그러면 운동도 더 안하게 되는 거죠. 운동해도 하 나도 안 바뀌는데 먹으니까 당연히 운동 안 하는 거죠.

그녀들에 따르면, 간식을 먹는다는 것은 다이어트 포 기이고, 다이어트 포기는 운동 중단의 중요한 이유이다. 그녀들에게 신체활동이란 단지 다이어트의 수단이었음 을 추론할 수 있다. 이러한 이야기 과정에서 주목해야 하 는 것은 다이어트든 미용이든 간에 그녀들 역시 운동이 필요하다는 것에 동의하고 있다는 것이다. 이렇게 볼 때, 연구참여자들의 두 번째 특성은 신체활동이 필요하다고 생각하고 있는 학생들이다.

신체활동이 저조한 여학생들은 스스로 의지가 없다고 말하지만, 그녀들 역시 신체활동의 필요성을 자각하고 있 다. 의지는 있으나 실제로의 신체활동으로 실천되지 않고 있을 뿐이다. 이런 점에서, 신체활동이 저조한 여학생이 란 '의지는 있으나 행 동력이 약한 여학생'으로 이해되며, 이것은 연구참여자를 이해하는 핵심적인 특성이다.

\section{자료 수집과 분석}

포토보이스의 자료 수집은 오리엔테이션, 포토보이스 실행, 포커스 그룹 면담으로 구성된다(Baker \& Wang, 2006). 첫째, 오리엔테이션 단계에서는 연구참여자가 연 구 전반을 이해하고 포토보이스 실행 방법에 대한 설명이 이루어진다. 연구자는 연구 의의, 사진 찍는 요령, 사진을 찍는 과정에서 발생할 수 있는 윤리적 문제 (예, 타인이나 소유하고 있는 물건을 찍어야 할 때는 반드시 동의를 구
해야 한다 등) 등에 대해 설명하였다. 둘째, 포토보이스 실행 단계에서 연구참여자는 주어진 2 주의 기간 동안 초 기 질문과 관련된 사진(약 20 25장)을 찍는다. 초기 질 문은 "일상생활에서 당신의 신체활동을 방해하는 것은 무 엇인가요?"였으며, 연구참여자들은 2019년 12월 6일 19일 (2주간)까지 찍었다. 셋째, 찍어 온 사진의 선택(연 구자 2장, 참여자 2장)이 완료된 직후 포커스 그룹 면담 을 실시하였다. 포커스 그룹 면담은 2019년 12월 23일 (파랑중)과 24일 (노랑중) 양 일에 걸쳐, 컴퓨터와 빔프로 젝터가 설치된 장소에서 약 3 시간 정도씩 진행되었다.

포커스 그룹 면담 과정을 살펴보면, 연구참여자 한 사 람당 연구자가 선정한 2장과 참여자가 선정한 2장 총 4장 씩의 사진이 활영된다. 연구참여자들이 찍어 온 사진은 총 224장이었으나, 포커스 그룹 면담에서는 48장 (4장*6 명*2회)의 사진을 활용하였다. 포커스 그룹 면담은 화면 에 사진을 띄우고, 그 사진을 찍어 온 연구참여자가 사진 을 찍은 이유를 설명하면, 연구자는 $\mathrm{SHOWeD}$ 기법2)으 로 알려진 질문들을 그룹 면담 참여자들에게 물어보았다. 이때, 다섯 가지 질문 중 사진을 찍어 온 참여자의 이야기 나 사진의 내용에 맞게 질문을 선택 및 재구성하게 되는 데, 예를 들면, CCTV 사진은 이곳에서 신체활동을 한다 면 어떻게 될까?, 신체활동을 하면서 어떤 걱정을 하게 될까? 등의 질문으로 진행되었다. 간식 사진을 그룹 면담 할 때는 간식은 여학생의 어떤 마음을 상징하는가?, 간식 과 운동, 그리고 삶은 어떤 관련이 있는가? 등을 중심으 로 진행되었다. 단, 연구자는 질문 이외의 대화를 독려하 거나 어떤 대답을 유도하는 등 참여자들 사이의 대화에 개입하지 않았으며, 참여자들 간 대화는 자유롭게 진행되 었다. 수집된 자료는 텍스트로 변환되었다. 한편, 포커스 그룹 면담 이후 추가적인 자료가 필요한 경우, 필요에 따 라 개별 면담이나 무선 전화 면담을 실시하였으며, 이를 통해 수집된 자료 역시 포커스 그룹 면담 자료와 함께 분 석되었다.

2) $\mathrm{SHOWeD}$ 기법은 (1)이 사진에서 무엇이 보입니까?(See) (2) 이 사진 속에는 무슨 일이 일어나고 있습니까?(Happening)? (3)이 사진은 우리의 삶과 어떤 관련이 있습니까? (Our) (4)왜 이런 문제, 걱정 혹은 장점들이 존재합니까(Why \& Exist)? (5)이것들을 위해 우리가 무엇을 할 수 있습니까? (Do)의 질문 으로 구성된다(Catalani \& Minkler, 2010을 Kim \& Lee, 2013b, p. 29에서 재인용). 
포토보이스의 분석과정은 사진 고르기, 맥락화, 주제 화하기의 과정으로 이루어진다(Wang, 1999). 사진 고 르기는 포커스 그룹 면담 전에 참여자별로 찍어 온 사진 중 4장(연구자 2장, 참여자 2장)을 선정하는 과정을 말하 고, 맥락화와 주제화는 포커스 그룹 면담을 통해 수집된 자료를 반복적으로 읽으면서 코드, 카테고리, 테마 등을 찾아 나가는 분석과정을 의미한다. 연구자는 일차적으로 텍스트로 변환된 자료를 반복적으로 읽으면서 연구참여 자의 환경적 맥락을 찾고자 노력하였다. 발견된 주요 환 경적 맥락은 크게 물리적 환경(공간, 시간 등), 사회적 환 경(관계, 인식 등), 제도적 환경 (학교체육 프로그램, 학 업 관련 제도 등)으로 나타났다. 맥락화 과정을 통해 분류 된 자료를 분류해 주제별로 묶는 주제화 작업은 연구참여 자들의 생활영역(학교영역, 교통영역, 여가영역, 가정영 역)을 중심으로 이루어졌다.

\section{연구의 진실성}

삼각검증과 동료 검증을 중심으로 연구의 진실성을 확 보하기 위해 노력하였다. 삼각검증 과정을 살펴보면, 본 연구에서는 학교체육 전문가 1 명, 질적연구 전문가 1 명, 여학생 체육 전문가 1 명을 전문가 협의회로 구성하였으 며, 자료 분석과정에서 공식적으로 2 회의 협의회를 실시 하였다. 1 차 회의에서는 연구자가 작성한 분석 초안을 토 대로 연구의 전경과 후경을 나누는 작업을 도움받았다. 신체활동 제약요인을 둘러싸고 있는 환경적 맥락들이 중 심으로 드러나야 한다는 조언을 받았고, 이를 중심으로 분석하였다. 2 차 회의는 연구텍스트가 완성된 후 사회생 태학 모델에 따라 여학생의 일상생활 신체활동 증진 방안 을 구체화하는 작업을 도움받았다. 그 외 자문이 필요할 경우 무선 전화나 이메일을 활용하였다. 또한, 완성된 연 구텍스트를 연구참여자들에게 보내어 동료 검증을 받았 다. 검증 과정에서 문제가 제기되지 않았고, 모든 참여자 들에게 연구텍스트에 대한 동의를 얻었다. 더불어, 자기 성찰과정을 통해 연구자 스스로 편견이나 선입견에 빠지 지 않도록 노력하였다.

\section{연구결과}

연구참여자들이 일상생활에서 경험하는 신체활동 제 약문제는 신체활동이 일어나는 생활영역 (여가영역, 교통 영역, 가정영역, 학교영역)에 따라 범주화되었으며, 각 영역에서 나타나는 문제들은 다음과 같이 나타났다.

\section{여가영역: 황무지 같은 놀이터}

연구참여자들이 선택한 사진들 중에는 시험, 학원, 공 부, 숙제, 학교 수행평가 등과 같은 학업과 관련된 사진들 이 유독 많았다(Figure. 3 참조).

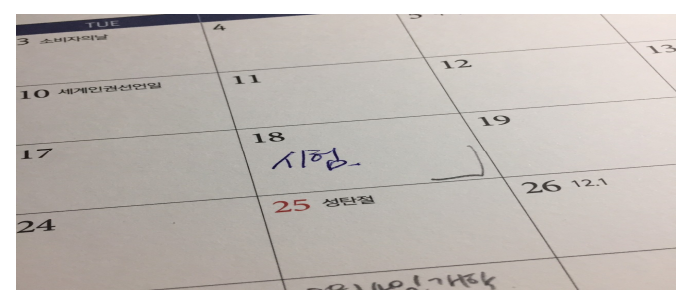

Fig. 3. calendar with exam dates

시험 공부하느라고 나가서 운동할 시간이 없었어요. -Chiwol(칠월)-

이런 사진들과 관련된 포커스 그룹 면담에서 연구참여 자들은 학교, 학원, 집이라는 쳇바퀴 같은 일상에서 운동 할 시간이 없다고 아우성이었고, 잠시 잠깐 마음 편하게 놀 수 있는 시간조차 없다고 항변하였다. "시험 때 말고도 그렇게 바쁜가요?" 라는 연구자의 질문에 "never"라고 짧 고 강하게 말하거나, "학원이 없어지지 않는 한..."이라는 자조 섞인 반응을 보였다. 하루 대부분이「학교, 학원, 숙 제」으로 채워지는 그녀들에게는 학업이라는 일 이외의 시간은 주어지지 않고 있다.

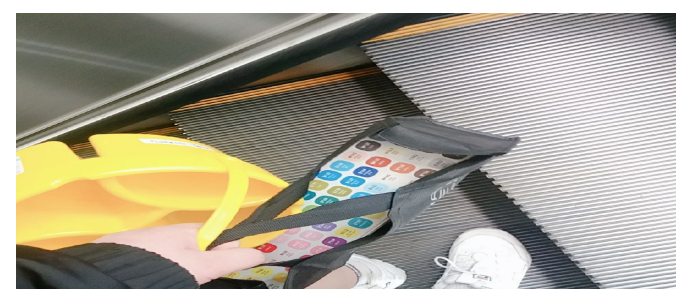

Fig. 4. art tools 
저게 마카랑 물통이거든요. 미술 도구예요. 저한테는 그 림 그리기라는 취미가 있는데 이게 앉아서 하는 취미니까 이 시간에는 운동하지 않는 거죠. ...(중략)... 제 스케줄 안에 운동이 낄 시간이 없는 거에요. -Ewol(이월)-

물론 아무리 바쁜 대한민국의 중학생이라고 해도, 여 가시간이 전혀 주어지지 않는 것은 아니었다. 그러나, 〈Figure 4〉의 이월이 말하는 것처럼 그 시간은 미술, 피 아노, 영화, 독서 등과 같은 그녀들의 비-활동적인 취미 생활로 채워지고 있었다.

그녀들의 문제는 의지의 문제인가? 아니면, 시간의 문 제인가? 전자의 측면에서 시간 부족(lack of time)은 의 지가 부족한 이들의 편리한 변명으로 지적된다(Sallis \& Owen, 1999). 그러나 시간 부족은 신체활동 참여가 저 조한 이들이 밝히는 첫 번째이자 가장 빈번하고 근본적인 문제이다(Nahas et al., 2003). 일례로, 학업을 강조하 는 NCLB(No Child Left Behind) 법안이 이후로 미국 청소년의 신체활동은 현저히 감소한 것은 학업 강조로 신 체활동 참여시간이 부족해졌기 때문이다 $\mathrm{CPPSE}$, 2013). 일반적으로 여학생의 신체활동은 남학생들에 비해 학업 요인에 더 큰 영향을 받는데, 이는 여학생들은 놀이보 다는 일 곧 공부를 우선 순위에 두기 때문이다(Thompson et al., 2005). 이러한 측면에서, 여가영역의 첫 번째 제 약요인은 '시간 부재'이다.

두 번째 제약요인은 '함께할만한 것 부재’이다. 위의 〈Figure. 4〉와 관련된 삼월의 이야기는 이를 이해할 수 있는 단초를 제공한다.

취미 자체가 운동이 아닌 게 문제가 아니라, 남자애들은 축구 가지고 함께 모이잖아요. 하지만 저희는 화장품 뭐 이 런 걸로는 함께 모이는데 운동 같은 걸로는 함께 모이지 않 으니까 운동할 수 없는 거예요. 학교에서는 체육수업이랑 스 포츠수업에 운동가지고 함께 모이니까 운동할 수 있는데 학 교 밖에서는 그럴 일이 없는 거죠. 함께 모여서 할 것 자체가 없으니까 운동으로 함께 모이지 않고 그러니까 운동도 하지 못하는 거죠. - Samwol(삼월)-

여학생들에게 ‘함께’는 신체활동의 중요한 문제임에 분 명하다. 신체활동 동료는 여학생의 신체활동 자발적 참여 를 결정하는 가장 중요한 사회적 자원이다(Stuntz \& Weiss, 2010). 또한 여학생들은 팀원들과의 관계 문제를
스포츠 클럽 활동을 중단하는 중요한 원인으로 설명한다 (Patrick et al., 1999; Slater \& Tiggemann, 2010). 사회적 관계를 중시하는 여학생의 모습은 우리나라 학교 체육 현장에서 종종 보게 되는데, 문제는 사회적 관계 (social relationship)로 인해 여학생의 신체활동 수준이 상대적으로 부정적인 영향을 미친다는 것이다(Slater \& Tiggemann, 2010). 왜냐하면, 여학생은 함께 할 동료가 있을 때 신체활동에 참여할 수 있는데, 삼월의 주장처럼, 그녀들에게는 함께 할 만한 신체활동 꺼리가 없기 때문이 다. 이런 점에서, 여학생들을 모을 수 있는 매력적인 신체 활동 꺼리가 필요하다.

세 번째로 확인된 여가영역 신체활동 제약요인은 '공간 부재'이다. 춥거나 더운 날, 강한 햇빛 등의 야외 환경 조 건은 여학생을 야외로 나오지 못하게 만드는 요인이다 (Slater \& Tiggemann, 2010). 물론 연구참여자들 역시 기온이나 햇빛을 상징하는 사진을 통해 여전히 이런 환경 조건이 제약으로 작용하고 있다고 말하고 있었지만, 다수 의 연구참여학생들이 뽑은 기후 환경과 관련된 제약요인 은 미세먼지로 대표되는 오염된 대기 환경이다(Figure 5 참조).



Fig. 5. fine dust \& ultra fine dust

이건 지난 주 미세먼지와 초미세먼지 보여주는 핸드폰 화 면이에요. 환경이 요즘 들어 많이 안 좋아지면서... 미세먼 지와 초미세먼지 높아져서 밖에서 하는 운동은 건강에 안 좋 으니까 야외에서 하는 운동은 안 좋으니까 안해야 하는 거라 고 생각해요. -Palwol(팔월)-

미세먼지 많은 날은 밖에 나가면 안 된다고 생각해요. 바 깥으로 나가지 말아야 하니까 운동도 할 수 없는 거죠. -Samwol(삼월)-

특히, 미세먼지 수치가 일종의 공포 기제로 작동하여, 미세먼지 나쁨 단계는 바깥출입 자체를 하지 말아야 하는 
경고등으로 인식하고 있었다. 대기 오염보다 죽음에 이르 게 하는 더 높은 순위에 있는 것이 좌식활동인데도 불구 하고(Kohl et al., 2012), 대기 오염으로 인한 건강공포 가 움직임 자체를 가로막고 있다.

최근 들어, 운동 공간이 부족한 도심에서 인도는 대체 공간으로 각광 받고 있다. 매력적인 인도(혹은 길)는 야 외에 있는 시간을 증가시킴으로써 신체활동 증진에 기여 한다. 그러나 여학생들에게 인도는 운동을 위한 매력적인 공간이 아니다. 〈Figure 6〉은 길이 안전하지 않은 공간이 라는 것을 보여준다.

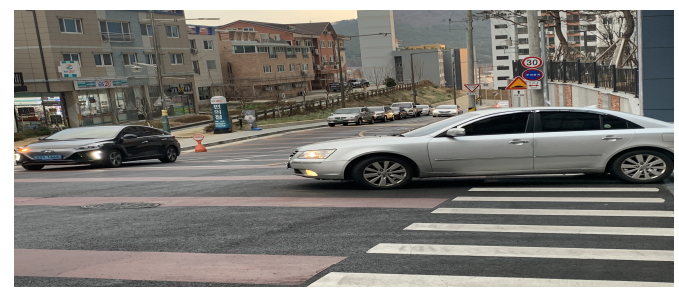

Fig. 6. crosswalk

횡단보도요. 여길 건너야 운동을 할 수 있는데, 차들이 막 달리니까 위험해서 여기 건너기 무서워요. 사고당할까 봐요. 도로가에서 운동하는 거 완전 무서워요. -Sawol(사월)-

이 밖에도 공사장 사진, 공사장 주변에 방치된 길 위의 적재물 사진, 그리고 개 조심 문구가 적혀 있는 사진 등은 도시 지역의 길이 운동하기에 안전하지도 매력적이지 않 은 공간이라는 것을 알려준다.

길 말고도 공동 주택의 야외 공간이나 공원은 도시에 서 운동하기 적당한 환경이다. 그러나 CCTV가 설치된 그곳들은 또 다른 감시와 노출이 일어나는 공간이다. CCTV는 몰래 자신을 쳐다보는 눈이 있음을 상징하는 사 진이지만, 운동하는 자신의 모습에 대한 당당함을 갖지 못하는 혹은 운동하는 몸의 노출을 꺼리는 여학생들에게 CCTV는 타인의 시선을 의미한다(Lee, 2014). 즉, 타인 에게 노출되어 있는 공간 역시 그녀들에게 운동할 수 있 는 공간은 아니라는 것이다.

어둡게 나와서 그렇지만 이건 저희 아파트에 있는 CCTV 사진이에요. 그냥 저를 감시하는 것 같아서 저게 설치된 곳에 서는 운동하기 어려워요. 안전한 느낌은 들지만 누군가 보고 있는 것 같아요. 없으면 무섭고 있으면 싫고. -Owol(오월)-
지자체의 노력과 사설 센터 건립으로 여성들을 위한 다양한 운동 공간이 확충되고 있지만, 그 곳 모두 10 대 여학생들을 위한 공간은 아니다. 경제력과 운동 욕구를 가진 여성들을 위한 공간이다. 또한, 10 대 여학생들이 일 상에서 마주할 수 있는 운동 공간 역시 날씨와 대기 환경, 위험한 길, 그리고 감시와 시선 문제로 점점 더 줄어들고 있다.

신체활동 공간에 대한 접근성 (accessibility)과 가용성 (availability)은 신체활동의 중요한 사회적 요인이다 (Slater \& Tiggemann, 2010). 그러나 10대 여학생이 지역의 스포츠 센터 혹은 레크리에이션 시설에 접근하는 데 여러 가지 한계가 있다. 아동과 청소년의 신체활동 관 련 요인을 메타분석한 Biddle et al. (2011)에 따르면, 청소년들의 여가시간 신체활동은 스포츠 시설에 대한 접 근성보다는 야외에서 보낸 시간 관련 환경요인들, 예를 들어, 인도의 존재 여부와 상태(안전도 등) $(+)$, 횡단보 도의 안전도 인식 $(+)$, 대중교통 접근성 $(+)$, 거주지에 대한 위험 인식(-), 도로의 수나 혼잡 여부(-) 등에 영향 을 받는다. 오염된 대기 환경, 위험한 인도와 도로 환경, 주변의 시선 등은 야외 시간을 가로막는 장애물이자, 신 체활동의 대표적인 환경 제약요인이다.

우리나라 여중생들은 학업 중심 시간표에 메어 있다. 국외 연구들 역시 학업 문제를 여학생 신체활동 감소의 주요 원인으로 다루고 있으나, 학교 숙제량 문제로 보거 나(Slater \& Tiggemann, 2010), 심각하더라도 여고생 의 문제로 특정한다(Thompson et al., 2005). 반면, 우 리나라 학업 중심 시간표는 학교 문제를 넘어, 학원, 학원 을 마친 이후의 숙제 등과 같이 하루 생활 전체로 확장된 문제이다. 즉, 학업 중심 시간표는 여가영역 신체활동 자 체를 제약하는 근본적인 요인으로 작용한다는 것이다. 특 히 남학생에 비해 여학생에게 좀 더 심각한 것은 여학생 의 신체활동 의지가 낮기 때문이기도 하지만, 학업에 충 실한 여학생의 행동 성향이 작용한 결과이다(Slater \& Tiggemann, 2010). 남학생은 학업으로부터 이탈해 움 직이는 반면, 여학생들은 학업 이탈없이 움직이지 않는다 는 것이다. 또한 그녀들에게는 함께 할 친구들을 모을 만 큼 매력적인 신체활동 꺼리도 없으며, 심지어 그녀들을 최소한의 신체활동이 일어날 수 있도록 유도하는 야외 공 간도 주어지지 않는다. 신체활동 측면에서, 여가영역은 
황무지 같은 놀이터일 뿐이다. 이러한 측면에서, 여가영 역의 신체활동 문제는 개인의 의지나 동기 이전에 환경의 문제 최소한 이 둘의 상호작용 문제로 바라볼 필요가 있다.

\section{가정영역: 쉼과 좌식화된 놀이 공간}

여중생들에게 집안은 학교 밖에서 안전하게 운동할 수 있는 유일한 공간이다. 미세먼지나 길 위의 공포나, 감시 나 노출의 문제도 이곳에는 존재하지 않는다. 그러나 집안 영역 역시 연구참여학생들에게 운동할 만한 곳은 아니다.

먼저, 연구참여자에게 집은 쉬어야 하는 공간이라는 인식이 자리잡혀 있다. 이러한 인식은 침대, 곰 인형, 이 불 등과 같이 집의 안락함을 보여주는 사진들을 통해 확 인된다. 아래의 구월은 밖에서 지친 몸이 쉬어야 하는 곳 으로 집을 정의하고, 그러한 인식으로 운동하지 못한다고 밝히고 있다. 쉬어야 하는 집에서 운동이라는 또 다른 일 을 할 수 없다는 것이다.



Fig. 7. a a downy bedclothes

이건 제가 덮는 이불이에요. 이불은 푹신하고 안에 들어 가 있으면 움직이기 싫어서 운동을 안 하는 것 같아요. 한번 들어가면 못 나오는 곳이죠. ...(중략)... 학원에서 힘들에게 하고 들어왔고, 숙제까지 해야 하루가 끝나는 데 거기서 운 동까지는 할 수 없어요. 집에서는 그래도 쉬어야 하잖아요. -Guwol(구월) -

고된 일들이 마무리되면 일명 몰폰(몰래 폰하기)이라 불리는 야간 스마트폰 놀이로 하루를 마감한다. 잠들기 전 잠깐 한다고 시작하지만 스마트폰 놀이가 짧게 끝나기 만 하는 것은 아니다. 특히 유투브가 유행하게 되면서 한 두 시간을 훌쩍 넘겨 새벽 늦은 시간까지 유투브에 빠져 있는 일이 많아지고 있다고 한다.

한번 유투브를 시작하면 한 두 시간은 그냥 가요. 일단
들어가면 썸네일이나 유투브 알고리즘 때문에 끌리는 제목 이 계속 나오고 연관성 있는 영상이 계속 나오니까 계속 더 더 더 보게 되는 것 같아요. 평일 밤은 거의 유투브 보면서 하루를 끝내는 곳 같아요. - Sib-ilwol(십일월)-

평일 공부에 지쳐 늦게 귀가한 그녀들이 집 안에서 운 동을 하는 일은 쉬운 일은 아닐 것이다. 그러나 힘과 시간 이 남는다고 해서 집 안에서 운동을 하는 것은 아니다. 오 히려 주말의 하루는 보다 비활동적인 것들로 채워진다. 〈Figure 8〉처럼, 앉거나 누워서 할 수 있는 놀 거리들 (예, TV, 유투브, SNS, 스마트폰 놀이, 컴퓨터 등)로 주 말의 하루가 가득 채워질 뿐이다.

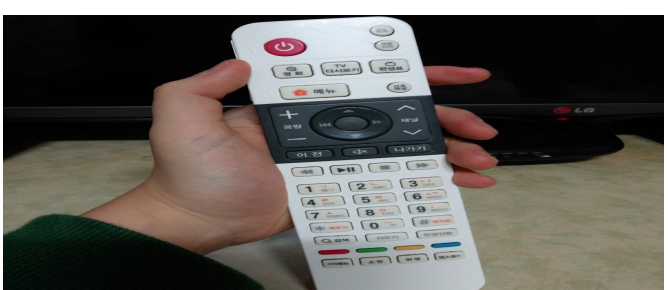

Fig. 8. TV Remote control

리모콘이에요. 주말에는 눈 뜨면서 손에 쥐고 계속 있는 것 같아요. TV는 거의 앉아서 보니까 운동하지 않는 거죠. 주말에는 평일에 못 본 것들까지 봐야 하니까 아침부터 밤까 지 앉은 자리에서 쭉 봐요. 주말에 TV 보는 시간이 컴퓨터나 핸드폰하는 시간이 더 많아요. 평일에는 볼 시간이 없으니까 핸드폰 하는 거고, 주말에는 편하게 느긋하게 볼 수 있는 거 죠. $-\operatorname{Siwol}($ 시월) -

청소년기 좌식화된 놀이 문화는 신체활동 감소의 주된 원인으로 지적되어 왔다(Lee, 2014). 좌식화된 문화가 성인들에 비해 청소년기에 보다 부정적인 영향을 미치는 것은 상대적으로 운동의 필요성을 덜 느끼기 때문으로 판 단된다(Biddle et al., 2010). 즉, 성인들은 건강을 위해 의도적으로 운동을 더 하려는 책무성을 더 갖고 있다는 것이다. 이와 같이, 좌식화된 놀이는 가정에서의 저조한 신체활동 문제를 일으키는 주요 원인이라 할 수 있다.

여기에 더해, 어른들의 전통적인 성역할 사회화 편견 (stereotype)의 축적된 역사가 가정영역에서 가족들과 함께 운동하는 문화를 억제하고 있다(Figure 9 참조). 


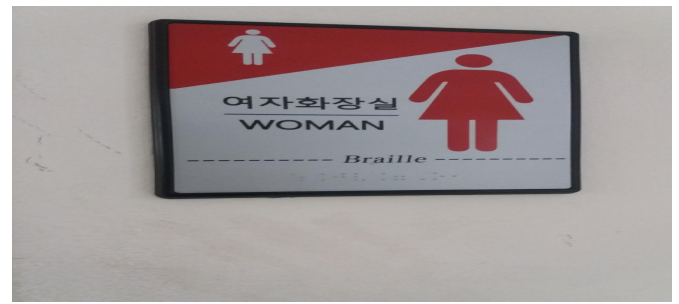

Fig. 9. a woman wearing on a skirt

여자화장실 표시에요. 여자를 치마 입은 모습으로 하잖 아요. 치마 입은 여자. 어렸을 때부터 진짜 밖에 놀러나가고 싶어도 못 나고 그랬어요. 여자라고요. 그러니까 어렸을 때 부터 가족들 그러니까 아빠나 엄마나 운동한 적이 없었어요. 지금도 "여자가 운동 하냐?" 이렇게 생각하는 분들 많고 요. -Ewol(이월) -

그렇게 생각하는 어른들 많아요. 남자애들이 뛰어놀면 장난 잘 친다 활발하다 이렇게 칭찬하는데 여자애들이 그러 면 살짝 여자가 그게 뭐냐? 하며 산만하다고 못하게 해요. 할머니들만 아니라 아줌마 아저씨들도 그렇게 말 많이 해요. -Samwol(삼월) -

여학생들은 어려서부터 가족과 함께 운동해 본 경험이 없다고 말한다. 어려서도 없는데 지금은 더 경험이 없을 수밖에 없다. 주요 타자 중 부모의 신체활동 지원이나 지 지는 청소년 신체활동의 주요한 긍정적 요인이다 (Stuntz \& Weiss, 2010). 반면, 성역할 편견을 조장하 는 말은 여학생의 신체활동 동기를 저하시키고(Slater \& Tiggemann, 2010), 신체활동 관련 과제 숙달 능력을 저 하시킨다(Hively \& El-Alayli, 2014). 성역할 사회화의 축적된 역사는 개인의 젠더 이데올로기를 만들어 운동에 대한 부적합한 정체성을 가질 뿐만 아니라 자발적 신체활 동의 주요 요인인 신체활동 동료의 가정 부재 현상을 일 으킴으로써 신체활동을 제약한다.

여가영역과 마찬가지로, 가정영역 역시 학업 중심 시간 표의 여파, 좌식화된 놀 거리, 그리고 젠더 이데올로기의 영향으로 신체활동이 파고들 여지가 크지 않다. 그럼에도 불구하고, 10 대 여학생들의 여가영역 신체활동 공간이 전 무한 현 시점에서 가정영역은 시간이나 할 거리도 없는 여 가영역을 대체할 수 있는 유일한 영역이다. 국외의 경우, 가정에서 가족들과 함께 하는 신체활동의 중요성을 강조 하며 가족 신체활동 프로그램(family program)을 개발
및 보급해 왔다(CPPSE, 2013). 반면, 우리나라는 신체 활동 관점에서 가정영역에 대한 관심은 크지 않았던 것이 사실이다. 10 대 여학생의 여가영역 신체활동이 줄어드는 상황에서 가정영역에 대한 관심을 기울일 필요가 있다.

\section{교통영역: 엄빠카로 대체된 교통수단}

학생들에게 교통영역은 학교를 중심으로 일어나는 일 상생활의 중요한 신체활동 영역이다. 연구들은 도보 등. 하교는 가벼운 신체활동을, 자전거 등하교는 MVPA에 영향을 미친다고 강조한다(CPPSE, 2013). 그러나 자동 차는 연구참여학생들의 교통영역 신체활동을 빼앗아 버 린다.

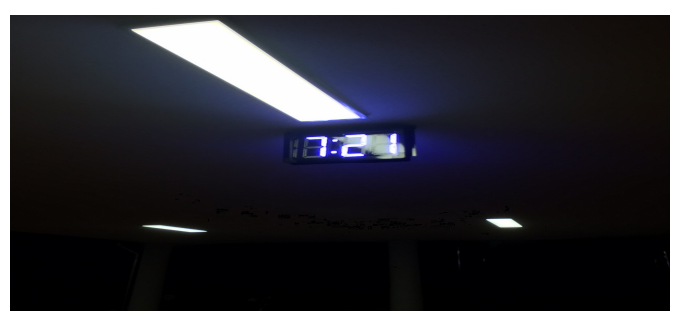

Fig. 10. 7:21 a.m.

이 사진에 나오는 7:21 이라는 숫자는 엄마 차타고 학교에 왔을 때 시계에 있었던 시간이에요. 걸어오면 한 20분 정도 걸리는데 엄마 차타고 오면 5 분이면 오거든요. 엄마 출근시간 에 와야 하는 게 그렇지만 편하잖아요. -Chiwol(칠월)-

다수의 연구참여학생들이 등교 교통수단으로 엄마.아 빠 자동차(엄빠카)를 이용하고 있다. 연구참여학생들은 10 분 이상 걸리는 거리에 살고 있는 학생들 대부분이 엄 빠카를 애용한다고 말한다. 학원으로 향하는 하교 시에도 교통수단은 학원차냐 엄빠카냐 일 뿐 자동차이다. 여중생 들에게 교통영역 $\mathrm{MVPA}$ 역할을 하는 자전거는 이용되지 도 않고 위험하다는 이유로 교칙으로 금하고 있다. 도보 등하교 역시 엄빠카로 대체되고 있다. 이런 점에서 학교 를 중심으로 하는 여중생의 교통영역 신체활동은 점점 더 줄어들 것으로 보인다. 


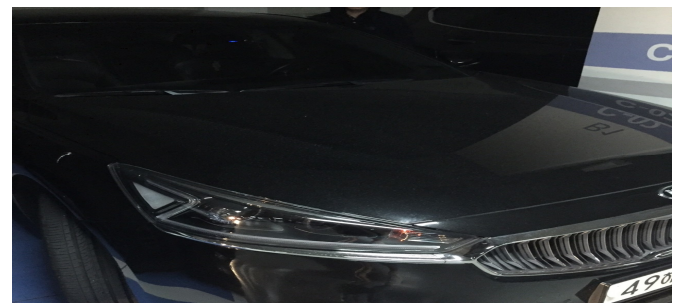

Fig. 11. daddy's car

이 차는 학교말고 다른 데 갈 때 타고 다니는 차 사진이에 요. 다른 데 갈 때는 이 차를 타거든요. 학원이나 이런 데 말 고 가족끼리 가거나 조금 먼 데 갈 때는 이 차로 데려다 주는 편이에요. -Chiwol(칠월)-

엄빠카는 등하교용으로 한정되지 않는다. 〈Figure 11>에서 보듯이, 연구참여학생 대부분은 주말 이동수단 역시 엄빠카를 애용하고 있다고 말한다. 학생들이 엄빠카 를 이용하지 않을 때는 주말에 친구들을 만나러 갈 때라 고 한다. 물론 경우에 따라 부모님이 데려다 주기도 하지 만 친구들과 만날 때는 대중교통을 이용하거나 걷는다고 말한다. 그러나 학업으로 바쁜 그녀들이 만나는 일은 한 달에 한두 번 있을까 말까하다고 한다. 결과적으로, 등하 교와 마찬가지로 교통영역에서 신체활동은 거의 일어나 지 않는다.

한편 배달시켜 먹은 떡볶이 사진을 선택한 구월은 외 식을 위해 차량으로 이동하는 일마저 점점 더 사라지고 있음을 보여준다. 배달의 편리함이 작은 움직임마저도 빼 앗아 가고 있다.

이건 배달시켜 먹은 떡볶이에요. 요즘은 배달이 안 되는 게 거의 없으니까 거의 배달시켜 먹잖아요. 이제 먹으러 가 지 않고 집으로 음식이 배달되어 오니까 더 운동하지 않는 거죠. -Guwol(구월) -

$\mathrm{CPPSE}$ (2013)에 따르면, 첫째, 교통 영역은 청소년 신체활동의 약 10 20\% 정도를 책임지는 영역이고, 둘 째, 걷거나 자전거를 타고 등하교 할 수 있을 정도로 안전 한 교통 환경이 중요하고, 셋째, 집과 학교의 거리가 짧지 도 않고 멀지도 않을 정도의 거리가 교통 영역 신체활동 에 유리하다. 그러나 여고생 교통영역이 차량으로 대체된 것 (Lee, 2014)과 마찬가지로 여중생의 교통영역 역시 좌 식화되고 있다. 이로 인해 일상생활에서 10 20\%의 신
체활동량이 사라지고 있는 중이다.

\section{학교영역: 유일한 운동 공간 그러나 젠더 차별의 재생산}

학교에서의 시간은 좌식활동들로 채워진다. 때문에 학 교는 신체적으로 부정적인 공간으로 규정되어 왔다. 〈Figure. 12〉는 연구참여학생들 역시 학교를 신체활동의 방해물로 여기고 있음을 알려 준다.

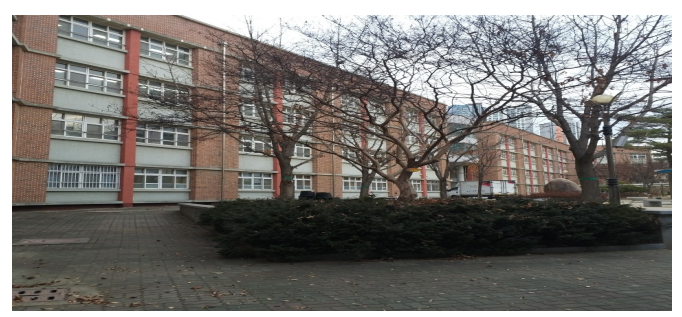

Fig. 12. my school

학교 사진이에요. 학교 오면 공부해야 하니까 운동을 못 하는 거예요. 앉아서 공부를 해야 하잖아요. -llwol(일월)-

그러나 〈Figure 12〉와 관련된 포커스 그룹 면담을 진 행하는 과정에서 한 학생의 질문, "학교 말고 딴 데서 운 동 해?”를 통해 학교의 다른 단면이 드러난다.

\footnotetext{
아니. 학교와야 운동하지. 체육시간만 운동하는데. -Sam- wol(삼월)-
}

운동 의지가 약한 여학생들은 학교 중 의무적인 체육 활동 시간에만 운동이라고 할 만한 강도의 신체활동을 하 고 있는 것이다. 팔월의 이야기에서 보듯이, 연구참여학 생들은 체육 수업시간이 다른 활동으로 대체되거나 빠지 는 것 자체를 신체활동 방해요인으로 생각한다.

저희 반 시간표에요. 체육이 일주일에 세 번 들어 있고 스포츠수업은 한 번 들어 있는데, 체육 든 날 진로체험이나 소풍 같은 것을 가면 체육이 빠지게 되잖아요. 운동하는 날 이 안하는 날이 되는 거거든요. -Palwol(팔월)-

학교는 좌식행동을 상징하는 공간이다. 왜냐하면, 학 교 시간의 대부분을 교실 수업이 차지하고 있기 때문이 다. 학교에 머무는 시간이 증가할수록 학생들의 신체활동 
시간이 줄어드는 것도 이 때문이다(Kang \& Lee, 2015; Pearson et al., 2017). 다른 측면에서 학교 체육활동이 일어나는 학교영역은 운동 의지와 욕구가 약한 여학생들 을 움직이게 하는 유일한 영역이다. 실제로, 여학생 신체 활동 특히 MVPA는 학교영역을 의존해 일어나고 있으며 (Kang \& Lee, 2015), 방학 중에 비해 학기 중 신체활동 이 높다(Jang, 2020; Lee \& Kang, 2016). 남녀 중학생 의 학기 중 체육수업이 있는 날(a)과 없는 날(b), 방학 중 하루(c)를 비교한 Jang(2020)은 신체활동 총량과 MVPA 모두 $a>_{b}>_{c}$ 순으로 밝히고 있다. 이러한 결과는 여학생의 신체활동이 학교, 특히 교육과정에 따라 의무적 으로 참여해야 하는 정과 체육활동에 의존해 있음을 알려 준다. 이런 점에서, 학교는 신체활동의 제약 공간인 동시 에 여학생들의 유일한 신체활동 공간이다.

그러나 여학생들에게 학교영역은 신체활동의 젠더 차 별적 공간이다. 연구참여학생들은 남학생들과 비교하며 학교의 신체활동 방해요소를 다음의 세 가지 측면으로 밝 히고 있다.

첫째, 남학생들에 비해 여학생들은 학교 내 신체활동 공간이 부재하다. 〈Figure 13〉은 잠겨 있는 체육관 사진 으로, 학교 내 운동할 공간이 부족하다는 것을 직접적으 로 보여준다.

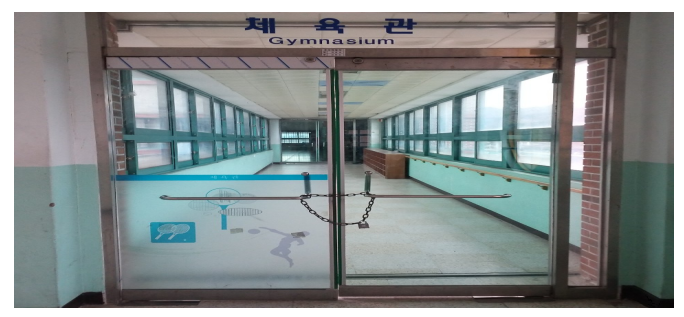

Fig. 13. Locked gym

체육관 문이 잠겨 있는 사진이에요. 점심시간에 체육관 을 걸어놔요. 이유는 잘 몰라요. 우리는 정말 편하게 운동복 차림으로 다니는데 운동할 공간이 없어요. -노랑중 일월-

잠긴 체육관 사진에 관한 포커스 그룹 면담 내용은 그것 이 단지 공간 부족의 문제만이 아니라는 것을 보여준다.

Samwol(삼월): 체육관도 걸려있고 운동장은 작은데 남자애 들이 다 쓰니까 별로 나가고 싶은 마음도 없고 나갈 시
간도 없어요. 나가도 할 것도 별로 없고요. ...(중략)... 체육선생님도 남자애들만 축구(방과후 체육활동) 가르 쳐주고 우리한테는 반(방과후 체육활동)도 안 만들어 주고요.

Ewol(이월): 그냥 체육관만 열어놓으면 남자애들이 또 다 할 게 분명해요. 그러니까 여자애들만 할 수 있는 프로 그램을 만들어서 운동장은 남자애들, 체육관은 여자애 들 이렇게 나눠줘야 여자애들도 운동할 수 있어요.

Samwol(삼월): 남자애들은 그냥 운동장만 있으면 축구가 유혹해서 개네들을 부르잖아요. 저희는 안 그렇거든요. 우리를 체육관으로 유혹해 줄 수 있는 게 있어야 해요. 그냥 체육관은 여자애들 공간이니까 해 이렇게 해 버리 면 별로 안 오거든요. 재미있는 걸 만들어서 여기에 올 수 있게 유혹해 줘야 하는데 그런 걸 우리 선생님들은 잘 안 해 주거든요. 그러니까 재미있는 프로그램을 만 들어서 불러줘야 여자애들도 운동한다는 거요.

위의 대화에서 알 수 있듯이, 공간뿐만 아니라 여학생 을 위한 체육활동 프로그램 역시 부재하다. 연구참여학생 들은 체육관이 열린다고 해서 여학생들의 차지가 되는 것 은 아니라고 한다. 왜냐하면 그녀들을 체육관으로 모이게 할 수 있는 프로그램이 없기 때문이다.

세 번째 요인은 시설의 부재이다. 시설 부재를 주장하 는 학생들은 여학생들을 위한 시설 자체가 부족하다고 지 적한다.

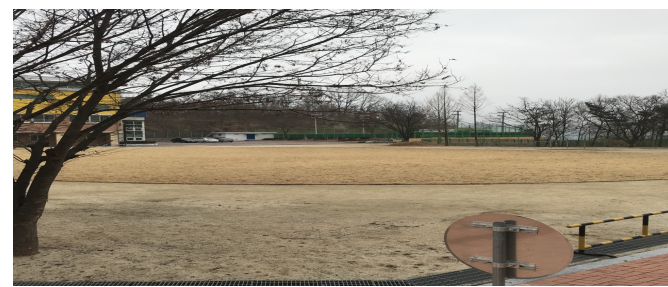

Fig. 14. An empty playgound

저희 학교 운동장인데 운동장에 아무 것도 없어요. 잔디 밖에 없어요. 철봉 몇 개 있고요. 운동할 데도 없는 이런 데 서는 운동할 마음이 안 들어요. -Palwol(팔월)-

학교는 여중생들이 마음 편하게 운동할 수 있는 유일 한 신체활동 공간이다. 그러나 학교영역이 학업 중심의 좌식행동 문화가 자리하고 있다는 것을 간과하지 말아야 한다. 과거 활동적이었던 다른 영역들이 비-활동적으로 바뀜에 따라 상대적으로 학교의 신체활동 기능과 역할이 
중요시 되어졌을 뿐이다. 여학생들은 학교영역에서 남학 생들과 비교되는 젠더 차별적 신체활동 경험을 하고 있 다. 이렇게 볼 때, 학교영역에서는 신체적으로 적극적인 환경으로 나아갈 수 있는 학교 환경 구축과 함께 젠더 차 별적 신체활동 경험을 해체하기 위한 노력이 병행될 필요 가 있다.

\section{논 의}

\section{여학생의 신체활동 제약 환경}

연구참여자들은 신체활동의 가치는 알지만, 참여하지 않는 여학생들이다. 그녀들은 왜 신체활동에 참여해서 그 수혜를 적극적으로 누리지 못하는 것일까? 이 연구에서 는 이 질문에 최근 신체활동 행동 습관의 잠재적 요인으 로 평가되고 있는 환경적 맥락에서 살펴보았고, 생활영역 별로 나타나는 연구참여자들의 제약 경험을 토대로 그녀 들을 둘러싸고 있는 환경 문제는 학업적, 물리적, 일상생 활적, 그리고 사회문화적 환경으로 확인되었다.

첫째, 학업적 환경이다. 연구참여자들은 학업 중심 시 간표에 따라 “학교-학원-집(숙제)-학교...”의 일상을 살아 간다. 오전 7시 21분 학교에 도착해 밤 9시에 집으로 돌 아가고 이후 새벽까지 숙제하는 칠월의 일과가 놀랍지 않 은 것은, 이러한 생활이 중학교 학생의 당연한 일상으로 자리하고 있다는 것의 반증일 것이다. 국외의 경우, 학업 과 신체활동 문제는 학교 과제 시간(Slater \& Tiggemann, 2010)이나 학교에서 보내는 시간 정도의 문제(Thompson et al., 2005)로 인식되었으나, NCBL 법안 이후 나타난 학령기 청소년의 급격한 신체활동 감소 로 이 문제는 신체활동 감소의 결정적인 요인으로 규정되 고 있다(CPPSE, 2013). 국제 비교 조사에서 동아시아 국가들(중국, 대만, 일본, 한국)의 신체활동 환경 지표가 $\mathrm{F}$ 등급인 것 역시 이들 국가의 높은 학업 시간에 따른 결 과이다(Tremblay et al., 2016). 즉, 학업으로 인한 시 간 부족 문제가 여학생 신체활동 문제를 야기하는 근본적 인 문제라는 것이다. 남학생 역시 시간 부족을 호소한다 는 점에서 학업 시간 문제는 여학생만의 문제는 아닐 것 이다.
그러나, 남학생에 비해 여학생은 신체활동 자발성이 낮고, 학업 충실도는 높다는 특성을 보이며(Slater \& Tiggemann, 2010), 그 결과, 학업 시간 문제는 여학생 에게 보다 근본적인 문제로 작용한다(Lee, 2014). 특히, “공부해야 해서 시간 없어”라는 핑곗거리가 여고생 시기 에 집중되는 국외(Thompson et al., 2005)와 달리 우리 나라에서는 중학교 시기에서부터 학업 문제로 신체활동 이 기피되고 있다는 점에 주목할 필요가 있다. 이러한 측 면에서, 학업 중심 생활은 여중생 신체활동의 근본적인 문제라 할 수 있다.

둘째, 물리적 환경이다. 물리적 환경은 직접적으로 신 체활동에 영향을 미치는 요인과 간접적 요인으로 구분된 다. 전자의 대표적인 요인은 시설의 접근성 혹은 가용성 등과 같이 신체활동과 직접적으로 관련된 환경이다 (Sallis et al., 2000). 전반적으로 여성의 신체활동 시설 접근성은 남성들에 비해 열악하지만, 여자 청소년은 보다 심각한 실정이다(Biddle et al., 2011). 경험적으로 국내 여학생의 신체활동 시설은 전무한 것이 현실이다. 여기에 더해, 최근 국내의 미세먼지 논란이 가중되면서 대기 오 염은 모든 연령대의 신체활동 제약요인으로 작용하고 있 으며 (Zang, 2018), 본 연구의 참여여학생들 역시 대기오 염, 도로 위험성 및 인도의 안전성 문제, 지역의 안전성 문제 등과 같은 간접적인 환경요인 문제를 지적하고 있 다. 환경의 간접적 제약요인은 야외에 머무는 시간을 감 소시켜 신체활동 참여시간에 부정적으로 작용하며 (Biddle et al., 2011), 이는 학업 시간 문제와 마찬가지 로 신체활동에 소극적인 여학생들에게 보다 부정적인 영 향을 미친다. 연구결과에서 여가영역을 황폐화라는 다소 과격한 용어로 표현하였는데, 이는 여가영역 내에 여학생 이 참가할 만한 신체활동 시설이 없을뿐더러 야외에서 있 을 만한 환경조차 제약되기 때문이다. 이러한 측면에서, 여학생의 신체활동을 방해하는 직·간접적 물리적 환경 여 인에 관심을 기울일 필요가 있다.

셋째, 여학생을 둘러싸고 있는 일상의 환경 역시 신체 활동을 제약한다. 38 개국 아동과 청소년의 신체활동 지 표를 분석한 Tremblay et al. (2016)에 따르면, 우수한 사회 기반 시설 (infra-structure)을 보유한 국가는 부족 한 국가들에 비해 낮은 신체활동과 높은 좌식활동 패턴을 보인다. 또한, 집안에서 잡일이 요구되는 삶은 신체활동 
수준의 중요한 요인이고(Tremblay et al., 2016), 교통 영역은 청소년 $\mathrm{MVPA}$ 의 핵심 영역 중 하나이다(CPPSE, 2013). 즉, 불편한 삶이 더 신체적으로 긍정적인 환경이 라는 것이다. 반면, 연구참여자들이 살아가는 일상의 영 역들은 안락함과 편리함으로 갖춰져 있다. 가정의 안락한 설비들이나 자동차라는 편리한 이동수단은 여학생들을 더 움직이지 않게 만들고 있다. 이와 같이, 일상의 편리한 삶은 여학생의 신체활동을 제약하고 있다.

넷째, 사회문화적 환경 문제이다. 사회적 측면에서, 여 학생들은 부모나 교사로부터 신체활동 관련 충분한 지원 을 받지 못하고 있으며, 함께할 신체활동 동료 역시 부족 한 실정이다. 부모와 교사의 역할모델, 지지와 지원은 신 체활동의 주요한 사회적 자원이며(Sallis et al., 2000), 우리나라 남녀 중학생의 경우, 신체활동 동료의 유무는 일상생활 신체활동 수준을 결정하는 가장 중요한 요인이 다(Kang \& Lee, 2016). 그러나 우리나라 여학생들에게 는 이러한 사회적 자원이 부족하다. 오히려 여학생들은 성역할사회화 편견에 따른 젠더 차별적 환경에 노출되어 있다. 젠더 편견적 언어는 여학생의 신체활동을 억제하고 (Micaelsson et al., 2019), 도전적인 신체활동 과제의 성공률을 낮추며(Hively \& El-Alayli, 2014), 조직화된 신체활동을 그만두게 하는 요인(Slater \& Tiggemann, 2010)으로 작용할 만큼 신체활동의 강력한 영향요인이 다. 무엇보다, 학교에서조차 신체활동 관련 젠더 차별이 양산되고 있다는 것은 심각한 문제이다. 이렇게 볼 때, 여 학생들은 성역할 편견 속에서 충분한 사회적 지원을 제공 받지 못하고 있다.

종합해 볼 때, 신체활동의 가치를 알고 있는 여학생들 이 신체활동에 적극적으로 참여하지 않는 이유는 비단 동 기와 능력(체력과 기술) 등과 같은 개인의 내적 문제뿐만 이 아니다. 여성에게는 일상생활의 환경 조건 자체가 방 해물이라는 Micaelsson et al. (2019)의 주장처럼, 개인 의 외적 환경 역시 그녀들의 신체활동 행동을 방해한다. 이러한 문제들이 여학생들에게 보다 심각하게 작용하는 것은 상대적으로 개인의 내적인 신체활동 역량이 부족한 이들에게 부족한 시간, 열악한 물리적 환경, 안락하고 편 리한 삶, 그리고 사회문화적 인식이 손쉬운 핑곗거리 혹 은 더 큰 제약요인으로 작용하기 때문이다. 이러한 측면 에서, 여학생의 일상생활 전반의 신체활동을 증진시키기
위한 실제적인 방안이 마련될 필요가 있다.

\section{사회생태학적 관점의 여학생 신체활동 증진 방안}

모든 여학생이 그렇지는 않겠지만, 적어도 체육교육 연구 분야에서 그려지는 여학생들은 이 연구의 참여 학생 들처럼 자발적인 동기보다는 외모나 미용 등과 같은 외적 동기에 의해 참여한다. 이러한 여학생의 신체활동 행동 변화는 동기 향상을 통해 가능하다. 동기 요인을 메타 분 석한 Stuntz \& Weiss(2010)는 공통적인 동기 향상 요 인을 자신감의 지각(feel competent doing), 자율성 (have chosen to do) 지각, 신체활동 즐거움(find enjoyable), 지지적 관계 (positive social support)의 네 가지로 설명한다. Wallhead \& Buckworth(2004) 역시 자신감(효능감), 결과 기대, 자율성, 관계성, 그리고 즐거 움으로 밝히고 있다. 중요한 것은 이들 요인의 미묘한 변 화(subtle changes)만으로도 신체활동 행동의 드라마틱 한 변화가 나타날 수 있다는 것이다(Stuntz \& Weiss, 2010).

이 연구는 인간 행동은 개인적 요인과 환경적 요인의 상호작용에 따라 변화된다는 사회생태학 모델의 기본 가 정을 바탕으로, 개인의 미묘한 변화에 영향을 미칠 수 있 는 환경적 요인을 탐색한 연구이다. 이에, 여학생 신체활 동 증진 방안을 사회생태학 모델 관점에서 제안하면 다음 과 같다. 다만, 이 연구에서는 연구결과가 지지하는 범위 내에서 다섯 수준 중 개인 내와 외의 수준을 제외한 조직, 공동체, 공공정책 수준의 대안을 제안하고자 한다.

먼저, 조직 수준에서 학교는 비용 효율적인 최적의 신 체활동 영역이다. 특히 여학생들에게 학교는 거의 유일한 신체활동 공간이다. 현재 학교의 공식적인 신체활동 프로 그램은 의무적인 프로그램(체육수업, 학교스포츠클럽 활 동 수업)과 자발적인 프로그램(방과후 체육활동)으로 구 분된다. 미국을 위시한 서구 국가들은 단발적인 학교 체 육활동으로는 충분한 신체활동을 제공할 수 없다고 강조 하며, Whole-of-School 모형을 기반으로 하는 포괄적 학 교기반 신체활동 증진 프로그램 (Comprehensive School based Physical Activity Promotional program, CSPAP)을 권장하고 있다(Lee \& Hong, 2017). $\mathrm{CSPAP}$ 는 학교를 중심으로 학교 전(before, 적극적인 등 
교 활동, 오전 체육활동 등)-중(during, 정규체육수업, 점심시간 활동 등)-후(after, 교내 스포츠, 대교 스포츠 등) 프로그램으로 구성된다(Castelli et al., 2014). 적극 적으로 학교에 등교 해 공식적 및 비공식적 신체활동 프 로그램을 제공해 학교 일과 중 충분한 신체활동 기회를 제공받고, 방과 후 적극적인 스포츠 활동 참여를 통해 여 가영역으로 확대를 목표로 한다. 또한, 가정 프로그램을 제공함으로써 가정 내에서의 신체활동을 독려한다 (Castelli et al., 2014). 즉, 학교 전반에서 신체활동을 제공하는 동시에 학교를 중심으로 일상생활 전반(교통, 여가, 가정 영역)의 신체활동을 증진시키는 것이다. 이와 같이, 학교에서는 $\mathrm{CSPAP}$ 의 아이디어를 차용하여 학교 를 중심으로 일상생활 전반의 신체활동을 증진시킬 수 있 는 하드웨어 시스템을 구축해야 하며, 더불어, 여학생 개 인의 신체활동 역량(자신감, 즐거움, 관계성, 자율성)을 증진시킬 수 있는 전략을 기반으로 세부적인 프로그램들 이 개발 및 운영되어야 한다. 이를 통해 학교를 중심으로 여학생의 양적 및 질적 신체활동 경험을 제고할 수 있다. 다음으로, 공동체 수준에서 살펴보면, 첫째, 가정 내 신체활동의 지지와 지원이 필요하다. 가정영역은 여러 가 지 제약 속에서 여학생 신체활동이 일어날 가능성이 높은 영역이다. 교육과정 체계를 갖추고 있는 학교와 달리 가 정영역의 신체활동 증진은 가족(부모의 조력 ++ , 형제 자매 신체활동 ++ )들의 노력을 통해 가능하다(Sallis et al., 2000). 즉, 가정 내에서 가족들과 함께 하는 신체활 동이 필요하다. 또한 현재 부모의 지나친 교통 지원으로 여학생의 교통 영역이 좌식화되고 있다. 이를 위해, 시간 효율성과 편리함에서 신체적 적극성으로의 인식적 전환 이 필요하다. 둘째, 공동체 곳곳에 여학생들의 신체활동 행동을 유발할 수 있는 운동 넛지 (nudge, 특정 행동을 유 발하기 위한 표시)가 개발될 필요가 있다. 신체활동 넛지 로 계단 칸칸마다 적혀 있는 칼로리 소비 정보, 엘리베이 터 앞에 계단을 이용하라는 표시 등이 대표적이다. 이와 함께, 노랑중의 삼월이 말하듯이 여학생을 유혹할 수 있 는 넛지 개발이 보다 요청된다. 셋째, 젠더 편향된 말들을 통해 여학생은 신체활동으로부터 점점 더 멀어지고 있다 는 기억하며, 가정과 지역사회에 자리하고 있는 성역할사 회화 편견에 대한 인식적 전환이 요청된다. 이상과 같이, 공동체 수준에서 여학생의 신체활동을 증진시킬 수 있는
방안들이 적극적으로 검토 및 실행되어야 한다.

마지막으로, 공공정책 수준에서 다양한 신체활동 증진 정책이 제기되어야 한다. 구체적으로, 대기 환경 문제 (미 세먼지 등)는 전 세대에 걸친 신체활동 문제를 양산하는 요인으로 작용하고 있다(Zang, 2018). 정책 분야에서는 대기 오염을 줄이는 정책과 함께 오염된 환경에서도 안전 하게 운동할 수 있는 환경 (실내 운동 공간 구축, 대기 오 염 차단 수단 등)을 마련하기 위해 노력해야 한다. 성인뿐 만 아니라 청소년들 역시 오염된 대기로 인해 신체활동의 제약을 받고 있음을 기억하고 이들에 대한 방안 역시 고 려되어야 한다. 둘째, 거주지의 안전성을 높이기 위한 정 책이 요청된다. 범죄율이나 도로 환경 (자전거 안전, 차량 밀집도, 인도의 안전 조건 등)은 신체활동의 중요한 요인 이다(Biddle et al., 2011). 공공정책은 이러한 지역의 안전성을 높이기 위해 노력해야 한다. 특히 현재 도로 환 경은 자동차를 중심으로 구축되어 있다. 최근 개정된 도 로교통법 (12조 3항) 일명 민식이법은 이를 보여주는 단 적인 예이다. 자동차 중심의 교통 환경이 사람(혹은 도 보) 중심으로 전환되어야 한다. 연구들은 자동차 운행 규 칙만 지켜도 이러한 환경이 쉽게 정착될 수 있다고 강조 한다(CPPSE, 2013). 셋째, 가장 궁극적인 대책은 학업 중심의 교육 문화를 해체하기 위한 정책적 노력이 지속되 어야 한다. 다른 어떤 나라보다 학교 안팎의 학업 시간이 높은 우리나라의 경우 학업 시간만 줄이더라도 역으로 신 체활동 시간이 증가할 것이다.

\section{결어 및 제언}

중학교 시기는 신체활동 행동 변화가 급격하게 나타나 는 시기로, 이 시기의 신체활동 행동 습관은 성인기로 이 어져 생애 전반의 라이프스타일 형성의 기틀이 된다 (Biddle et al., 2010). 여학생은 남학생들에 비해 '감소 된 신체활동과 증가된 좌식행동'의 패턴이 뚜렷하고 그 변화가 급격하다. 이 연구에서는 이러한 문제의식을 바탕 으로 중학교 여학생들이 일상생활 신체활동 문제를 환경 적 맥락에서 살펴보았고, 그 결과, 그녀들의 신체활동 제 약 경험은 황폐한 놀이터같은 여가영역, 좌식화 된 가정 영역, 엄빠카로 대체된 교통영역, 유일한 신체활동 공간 
이지만 젠더 차별이 일어나는 학교영역으로 범주화되었 으며, 그녀들을 둘러싸고 있는 환경적 제약요인은 학업 적, 물리적, 일상생활적, 그리고 사회문화적 환경으로 분 석되었다. 청소년 건강문제는 국제적 공동 대응을 필요로 할 만큼 세계적인 문제임을 기억해야 한다(Booth, 2000). 이는 여학생 신체활동 문제가 여학생 개인이나 가정, 그녀들의 건강 교육을 책임지는 학교, 심지어 한 국 가만의 힘으로 해결할 수 없는 문제임을 시사한다. 이러 한 측면에서, 신체활동 문제를 포괄하는 청소년 건강문제 는 개개인의 노력과 더불어 학교를 위시한 공동체(가정 과 지역사회), 그리고 공공정책 분야의 공동 대응을 필요 로 하는 과제이다.

마지막으로, 향후 연구 주제를 밝히면, 첫째, 지역적 특성을 반영하는 연구들이 요청된다. 이 연구를 포함한 기존 연구들은 대체로 도시 지역의 여학생을 연구참여자 로 삼고 있다. 그러나 신체활동 행동은 지역의 환경 여건 (예, 시골과 도시)에 영향을 크게 받는다. 지역의 특수한 환경 맥락을 반영하는 연구가 필요한 이유이다. 둘째, 젠 더 요인을 강조한 Slater \& Tiggemann(2010)의 연구처 럼, 남학생과 차별된 신체활동 제약 상황에 초점을 둔 연 구가 요청된다. 이러한 연구를 통해 학교영역을 포함한 일상생활 영역의 젠더 차별적 요소들이 보다 심층적으로 이해될 필요가 있다. 셋째, 학교급별 특성을 반영해 여학 생 신체활동 제약을 분석한 Thompson et al. (2005)과 같이, 연령과 학교급의 특수한 문화적 요인을 반영하는 연구가 요청된다. 넷째, 제약요인 분석을 통해 확인된 문 제 상황을 개선하기 위한 정책 및 프로그램 개발 연구가 필요하다. 이를 통해, 학교 체육활동에 의존하고 있는 청 소년 신체활동 정책을 벗어나 학교, 지역, 정책이 공동으 로 대응하는 신체활동 정책으로 확대될 필요가 있다.

\section{참고문헌}

Baker, T. A., \& Wang, C. C. (2006). Photovoice: Use of a participatory action research method to explore the chronic pain experience in older adults. Qualitative Health Research, 16(10), 1405-1413.

Barnett, T. A., O’Loughlin, J., \& Paradis, G. (2002). One-and two-year predictors of decline in physical activity among inner-city schoolchildren. American journal of preventive medicine, 23(2), 121-128.

Berger, B. G. (1996). Psychological benefits of an active lifestyle: What we know and what we need to know. Quest, 48(3), 330-353.

Biddle, S. J., Atkin, A. J., Cavill, N., \& Foster, C. (2011). Correlates of physical activity in youth: a review of quantitative systematic reviews. International Review of Sport and Exercise Psychology, 4(1), 25-49.

Biddle, S. J., Pearson, N., Ross, G. M., \& Braithwaite, R. (2010). Tracking of sedentary behaviours of young people: a systematic review. Preventive medicine, 51(5), 345-351.

Booth, M. (2000). Assessment of physical activity: an international perspective. Research quarterly for exercise and sport, 71(2), 114-120.

Castelli, D. M., Carson, R. L., \& Kulinna, P. H. (2014). Special issue: Comprehensive school physical activity programs. Journal of Teaching in Physical Education, 33(4), 435-439.

CPPSE(Committe on Physical Activity and Physical Education in the School Environment) (2013). Educating the Student Body: Taking Physical Activity and Physical Education to School. Washington, D.C.: The National Academic Press.

Green, L. W., Richard, L., \& Potvin, L. (1996). Ecological foundations of health promotion. American journal of health promotion, 10(4), 270-281.

Hively, K., \& El-Alayli, A. (2014). "You throw like a girl:” The effect of stereotype threat on women's athletic performance and gender stereotypes. Psychology of Sport and Exercise, 15(1), 48-55.

Jang, J. (2020). Comparative analysis of daily physical activity of male and female middle school students according to time period (during vacation and semester) and whether there is physical education class during semester. theses (Master's degree). Daegu: Kyungpook National University Graduate School.

Kang, H, \& Lee, G. (2015). Comparison of Levels and Areas of Physically Active Lifestyle among Female Students in Korean Elementary, Middle, and High Schools. The Korean Journal of Physical Education, 54(6), 197-208.

Kang, H, \& Lee, G. (2016). Analyses of relationships between societal factors and moderate vigorous physical activity, physical self-efficacy, and enjoyment among Korean 
elementary school students in fifth and sixth grade. The Korean Journal of Physical Education, 55(3), 249-259.

Kim, K. \& Lee, G. (2013a). Crisis in Qualitative Research and New Paradigm of Qualitative Research in Kinesiology. The Korean Journal of Physical Education, 52(2), 251-264.

Kim, K. \& Lee, G. (2013b). Retired Female Athlete’ Social Barriers and Alternative Strategies: A Photovoice Study. Korean Journal of Sociology of Sport, 26(3), 25-52.

Kohl, H. W., Craig, C. L., Lambert, E. V., Inoue, S., Alkandari, J. R., Leetongin, G., ... \& Lancet Physical Activity Series Working Group. (2012). The pandemic of physical inactivity: global action for public health. The lancet, 380(9838), 294-305.

Lee, G. (2014). Exploring on physically active lifestyle pattern and constrains of high school girl in city. Korean Journal of Sport Science, 25(4), 860-879.

Lee, G. (2019). Assessment of Levels of Moderate-to-Vigorous Physical Activity in Physical Education Classes Using 3-Dimensional Accelerometer: Competition Domain. Korean Journal of Sport Science, 30(2), 258-268.

Lee, G., \& Hong, D. (2017). Navigating the Role of Health Promotion in K-12 Physical Education: Implication of School-Wide Moderate to Vigorous Physical Activity Programs. Korean Journal of Sport Pedagogy, 24(4), 1-34.

Lee, G., \& Kang, H. (2015). An Analysis of Gender Difference on Physically Active Lifestyle among Korean Middle School Students. Korean Journal of Sport Pedagogy, 22(1), 53-70.

Lee, G., \& Kang, H. (2016). Analysis of Levels of Physical Activity between Semester and Vacation among Middle School Students: Using Three Dimensional Accelerometer. The Korean Journal of Physical Education, 55(4), 253-261.

MCST(Ministry of Culture, Sports and Tourism(2018). 2018 SURVEY ON CITIZENS' SPORTS PARTICIPATION. Sejong: Ministry of Culture, Sports and Tourism.

Mikaelsson, K., Rutberg, S., Lindqvist, A. K., \& Michaelson, P. (2019). Physically inactive adolescents' experiences of engaging in physical activity. European Journal of Physiotherapy, 1-6.

Morton, K. L., Atkin, A. J., Corder, K., Suhrcke, M., \& Van Sluijs, E. M. F. (2016). The school environment and adolescent physical activity and sedentary behaviour: a mixed studies systematic review. Obesity reviews, 17(2), 142-158.

Nahas, M. V., Goldfine, B., \& Collins, M. A. (2003). Determinants of physical activity in adolescents and young adults: The basis for high school and college physical education to promote active lifestyles. Physical Educator, 60(1), 42-56.

NASPE (National Association for Sport and Physical Education) (2005). Is it physical education or physical activity? NASPE position statement. Strategies, 19(2), 33-34.

Patrick, H., Ryan, A. M., Alfeld-Liro, C., Fredricks, J. A., Hruda, L. Z., \& Eccles, J. S. (1999). Adolescents' commitment to developing talent: The role of peers in continuing motivation for sports and the arts. Journal of youth and adolescence, 28(6), 741-763.

Patterson,, E. (2010). Scoring_protocoal.pdf. IPAQ homepage (s ource: https://sites.google.com/site/theipaq/scoring-protocol).

Pearson, N., Haycraft, E., Johnston, J. P., \& Atkin, A. J. (2017). Sedentary behaviour across the primary-secondary school transition: A systematic review. Preventive medicine, 94, 40-47.

Sallis, J. F., \& Owen, N. (1999). Physical activity and behavioral medicine. Thousand Oaks, CA: SAGE Publications.

Sallis, J. F., Owen, N., \& Risher, E.B. (2008). Ecological Models of Health Behavior. In K. Glanz, B.K. Rimer, \& K. Viswanath (Eds.), Health Behavior and Health Education: Theory, Research, and Practice (4th ed.)(pp. 465-485). San Francisco: Jossey-Bass.

Sallis, J. F., Prochaska, J. J., \& Taylor, W. C. (2000). A review of correlates of physical activity of children and adolescents. Medicine \& science in sports \& exercise, 32(5), 963-975.

Sarkin, J. A., Thomas, L. McKenzie, T. L., \& Sallis, J. F. (1997). Gender Differences in Physical Activity during Fifth-Grade Physical Education and Recess Periods. Journal of Teaching in Physical Education, 17(1), 99-106.

Slater, A., \& Tiggemann, M. (2010). “Uncool to do sport”: A focus group study of adolescent girls’ reasons for withdrawing from physical activity. Psychology of sport and exercise, 11(6), 619-626.

Slater, A., \& Tiggemann, M. (2011). Gender differences in adolescent sport participation, teasing, self-objectification and body image concerns. Journal of adolescence, 34(3), 455-463.

Song, K., Park, H., Lee, H., \& Lee, T. (2010). Physical Activity Levels of 7th Graders in PE Class and Lunch Period. The Korean Journal of Measurement and Evaluation in Physical Education and Sports Science, 12(2), 53-64.

Stuntz, C. P., \& Weiss, M. R. (2010). Motivating children and adolescents to sustain a physically active lifestyle. American 
Journal of Lifestyle Medicine, 4(5), 433-444.

Telama, R. I. S. T. O., \& Yang, X. (2000). Decline of physical activity from youth to young adulthood in Finland. Medicine \& Science in Sports \& Exercise, 32(9), 1617-1622.

Thompson, A. M., Rehman, L. A., \& Humbert, M. L. (2005). Factors influencing the physically active leisure of children and youth: A qualitative study. Leisure Sciences, 27(5), 421-438.

Tremblay, M. S., Barnes, J. D., González, S. A., Katzmarzyk, P. T., Onywera, V. O., Reilly, J. J., \& Tomkinson, G. R. (2016). Global matrix 2.0: report card grades on the physical activity of children and youth comparing 38 countries. Journal of physical activity and health, 13(s2), S343-S366.
Wallhead, T. L., \& Buckworth, J. (2004). The role of physical education in the promotion of youth physical activity. Quest, 56(3), 285-301.

Wang, C. C. (1999). Photovoice: A participatory action research strategy applied to women's health. Journal of Women's Health, 8(2), 185-192.

Wang, C. C. (2006). Youth participation in photovoice as a strategy for community change. Journal of Community Practice, 14(1-2), 147-161.

Zang, P. (2018). The Impact of Particulate Matter on Outdoor Leisure Activities. theses(Master's degree). Seoul: Seoul National University Graduate School.

\section{여학생의 일상생활 신체활동을 제약하는 환경요인 탐색 : 포토보이스 \\ 이규일 \\ 경북대학교 부교수}

〔목적〕 이 연구의 목적은 중학교 여학생의 일상생활 신체활동을 제약하는 환경요인을 살펴보고, 사회생태 학 모델에 근거해 신체활동 증진 방안을 제안하는 것이다. 〔방법) 신체활동 수준이 낮은 여학생 12 명을 연구 참여자로 선정하여, 포토보이스 기법에 따라 자료를 수집(오리엔테이션, 포토보이스 실행, 포커스 그룹 면담) 및 분석(사진 고르기, 맥락화, 주제화하기)하였다. 〔결과) 연구참여자들의 일상생활 신체활동 제약 경험은 생 활영역별로 황무지 같은 놀이터(여가영역), 쉼과 좌식화된 놀이 공간(가정영역), 엄빠카로 대체된 교통수단 (교통영역), 유일한 운동 공간 그러나 젠더 차별의 재생산(학교영역)으로 범주화되었다. (결론) 일상생활 신 체활동을 제약하는 환경요인은 학업적 환경, 물리적 환경, 일상생활 환경, 그리고 사회문화적 환경으로 분석되 었고, 사회생태학 모델에 근거해 여학생 신체활동 증진 방안을 조직, 공동체, 공공정책 수준에서 제안하였다.

주요어: 여학생, 일상생활 신체활동, 환경적 제약요소, 사회생태학 모델, 포토보이스 